\title{
LIQUID CHROMATOGRAPHIC DETERMINATION OF SOLIFENACIN SUCCINATE, FLAVOXATE HYDROCHLORIDE AND TOLTERODINE TARTRATE IN BULK DRUGS AND THEIR PHARMACEUTICAL DOSAGE FORMS
}

\author{
ALI K. ATTIA ${ }^{1, *}$, EMAN Y. Z. FRAG ${ }^{2}$, GEHAD G. MOHAMED ${ }^{2}$, HEBA E. AHMED \\ ${ }^{\prime}$ National Organization for Drug Control and Research, P.O. Box 29, Cairo, Egypt \\ ${ }^{2}$ Chemistry Department, Faculty of Science, Cairo University, Giza 12613, Egypt
}

\begin{abstract}
A simple, precise, specific and accurate reversed phase HPLC (RP-HPLC) method has been developed for the determination of solifenacin succinate (SOLS), flavoxate $\mathrm{HCl}$ (FLXHC) and toltoridine tartarate (TOLT) in bulk and pharmaceutical dosage forms. The proposed RP-HPLC method was carried out using Xterra RP-18 column ( $5 \mu \mathrm{m}$ practical size, $25 \mathrm{~cm}$ x $4.6 \mathrm{~mm}$ i.d.). The flow rate, the injection volume and the detection wavelength were $1.0 \mathrm{~mL} / \mathrm{min}, 20 \mu \mathrm{L}$ and $200 \mathrm{~nm}$,

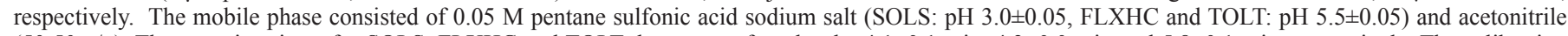
$(50: 50 \mathrm{v} / \mathrm{v})$. The retention times for SOLS, FLXHC and TOLT drugs were found to be $4.1 \pm 0.1 \mathrm{~min}, 4.3 \pm 0.0 \mathrm{~min}$ and $5.8 \pm 0.1 \mathrm{~min}$, respectively. The calibration was linear over the concentration range of $0.1-100 \mu \mathrm{g} / \mathrm{mL}$. The mean recoveries for SOLS, FLXHC and TOLT drugs were about $99.80 \%, 100.43 \%$ and $100.00 \%$, respectively. The method was validated according to the ICH guidelines with respect to specificity, linearity, accuracy, precision and robustness.
\end{abstract}

Keywords: Solifenacin succinate, Flavoxate HCl, Toltoridine tartarate, RP-HPLC.

\section{INTRODUCTION}

Solifenacin succinate (SOLS) is a competitive muscarinic-receptor antagonist for the treatment of overactive bladder with symptoms of urge urinary incontinence, urgency and urinary frequency. It is highly selective for muscarinic M3 receptor which is believed to be important in the modulation of bladder function. It reduces smooth muscle tone in the bladder, allowing the bladder to retain larger volumes of urine and reducing the number of micturition, urgency and incontinence episodes $[1,2]$.

Flavoxate $\mathrm{HCl}$ (FLXHC) is described as a smooth muscle relaxant but it also has antimuscarinic effects. It is a tertiary amine and is used for the symptomatic relief of pain, urinary frequency, and incontinence associated with inflammatory disorders of the urinary tract [3].

Tolterodine tartarate (TOLT) is the first drug to be developed specifically for the treatment of overactive bladder [4], figure 1 shows the chemical structures of SOLS, FLXHC and TOLT drugs [5].<smiles>Cc1ccc(O)c([C@H](CCN(C(C)C)C(C)C)c2ccccc2)c1</smiles>

Fig. 1: Chemical structures of SOLS, FLXHC and TOLT drugs.

Literature survey revealed that few chromatographic methods for SOLS [6-17], FLXHC [18-21] and TOLT [22-29], spectrophotometric methods for SOLS $[30,31]$, FLXHC $[32,33]$ and TOLT [34-36], potentiometric method for the determination of FLXHC [37, 38], spectroflourimetric [39] and electrochemical voltammetric methods for the determination of FLXHC [40] and TOLT $[41,42]$ were reported for their determination in bulk, dosage forms and biological fluids.

The need to determine drugs at high sensitivity and wider ranges than the reported chromatographic methods, therefore in the present study, it was intend to develop a rapid, economical, simple, precise and more sensitive RP-HPLC method for the determination of SOLS, FLXHC and TOLT in bulk and dosage formulations showing very low detection limits and wider linear ranges for the used drugs.

\section{EXPERIMENTAL}

\section{Materials}

The purity values of SOLS, FLXHC and TOLT are 100.3, 100.5 and $99.72 \%$, respectively. SOLS, FLXHC and TOLT were obtained from Maltipharma pharmaceutical Company (Eygpt), Unipharma Pharmaceutical Company (Egypt) and Pfizer Pharmaceutical Company (Egypt) respectively. The dosage forms of the used drugs were purchased from the local market. Acetonitrile (HPLC grade) was purchased from Poch, Poland. Pentane sulfonic acid sodium salt was obtained from Sigma-Aldrich. Orthophosphoric acid $85 \%$ $(0.2 \mathrm{M}$, Adwic Co., Egypt) was used for $\mathrm{pH}$ adjustment. Deionized water was obtained from purification system (Veolia-Water, Pure Lab, Flex).

Equipments

Agilent 1100 (Germany) equipped with degasser (G1322A), quaternary pump (G1311A), auto sampler (G1313A), UV detector (G1314A) and X Terra RP-18 column ( $5 \mu \mathrm{m}$ practical size, $25 \mathrm{~cm}$ x $4.6 \mathrm{~mm}$ i.d.) was used. Analytical weighing balance (Radwag XA60/220/X), pH meter (HANNA HI 253) and vacuum filter pump (model XI 5522050 of Millipore) were used throughout the experiments.

\section{Preparation of mobile phase}

The mobile phase consisted of $0.05 \mathrm{M}$ Pentane sulfonic acid sodium salt (SOLS: pH 3.0 \pm 0.05 , FLXHC and TOLT: $\mathrm{pH} 5.5 \pm 0.05$ ) and acetonitrile $(\mathrm{ACE})$ in the ratio of $(50: 50 \mathrm{v} / \mathrm{v}) . \mathrm{pH}$ values were adjusted using $0.2 \mathrm{M}$ Orthophosphoric acid. The prepared mobile phase was filtered through a 0.45 $\mu \mathrm{m}$ filter under vacuum, degassed and sonicated for $5 \mathrm{~min}$. The mobile phase was used as diluent.

\section{Preparation of standard solutions}

Standard solutions were prepared by accurately weighing and transferring $10 \mathrm{mg}$ (SOLS), $20 \mathrm{mg}$ (FLXHC) and $20 \mathrm{mg}$ (TOLT) drugs, into three 100 $\mathrm{mL}$ clean dry volumetric flasks and dissolving them with mobile phase and completed to the mark with mobile phase. $5 \mathrm{~mL}$ of these stock solutions were transferred into three $50 \mathrm{~mL}$ volumetric flasks and diluted up to the mark with the same diluent to get final standard solutions of SOLS $(10 \mu \mathrm{g} / \mathrm{mL})$, FLXHC $(20 \mu \mathrm{g} / \mathrm{mL})$ and TOLT $(20 \mu \mathrm{g} / \mathrm{mL})$, respectively.

Preparation of pharmaceutical dosage forms solutions

Ten tablets and ten capsules were weighed and finely grounded to powder. 
Equivalent weights of $10 \mathrm{mg}$ of SOLS, $20 \mathrm{mg}$ of FLXHC and $20 \mathrm{mg}$ of TOLT were transferred into three $100 \mathrm{~mL}$ clean dry volumetric flasks containing 70 $\mathrm{mL}$ of mobile phase and the mixture was sonicated to dissolve the powder. The volume was made up to the mark with the same solvent. $1 \mathrm{~mL}$ of these stock solutions was transferred into three $10 \mathrm{~mL}$ and diluted to the mark with the mobile phase to get a final sample solution of SOLS $(10 \mathrm{mg} / \mathrm{mL})$, FLXHC (20 $\mathrm{mg} / \mathrm{mL})$ and TOLT $(20 \mathrm{mg} / \mathrm{mL})$, respectively.

\section{Chromatographic conditions}

At room temperature, the separation was carried out on Xterra RP-18 column ( $25 \mathrm{~cm} \mathrm{x} 4.6 \mathrm{~mm}$ i.d., $5 \mu \mathrm{m}$ practical size). The mobile phase consisted of $0.05 \mathrm{M}$ pentane sulfonic acid sodium salt (SOLS: $\mathrm{pH} 3.0 \pm 0.05$, FLXHC and TOLT: $\mathrm{pH} 5.5 \pm 0.05)$ and acetonitrile $(50: 50 \mathrm{v} / \mathrm{v})$. The flow rate was $1 \mathrm{~mL} \mathrm{~min}-$ ${ }^{1}$. The injected volume was $20 \mu \mathrm{L}$ and the eluents were monitored at $200 \mathrm{~nm}$.

Construction of calibration curve

Aliquots of standard drug solutions equivalent to $1-1000 \mu \mathrm{g} / \mathrm{mL}$ were transferred into a series of $10 \mathrm{~mL}$ volumetric flaks and completed to the mark with mobile phase. Triplicate of $20 \mu \mathrm{L}$ of each drug solution were injected and different chromatograms were recorded under the previously described chromatographic conditions. Calibration curves were constructed by plotting the peak area against the corresponding concentration in $\mu \mathrm{g} / \mathrm{mL}$.

\section{RESULTS AND DISCUSSION}

The present study was carried out to develop a sensitive, precise and accurate HPLC method for the analysis of SOLS, FLXHC and TOLT drugs in bulk powder and dosage forms under isocratic conditions, mixtures of 0.05 M pentane sulfonic acid sodium salt (SOLS: $\mathrm{pH} 3.0 \pm 0.05$, FLXHC and TOLT: $\mathrm{pH} 5.5 \pm 0.05)$ and acetonitrile in different proportions were tested as the mobile phase on a Xterra RP-18 column. A binary mixture of pentane sulfonic acid sodium salt buffers and acetonitrile in a 50:50 v/v proportion was proved to be the most suitable for the purpose since the chromatographic peaks obtained were well defined and almost free from tailing. The retention time obtained for SOLS, FLXHC and TOLT drugs were 4.1, 4.3 and $5.8 \mathrm{~min}$, respectively. Figures $(2,3)$ show the chromatograms of the used drugs and their dosage forms.
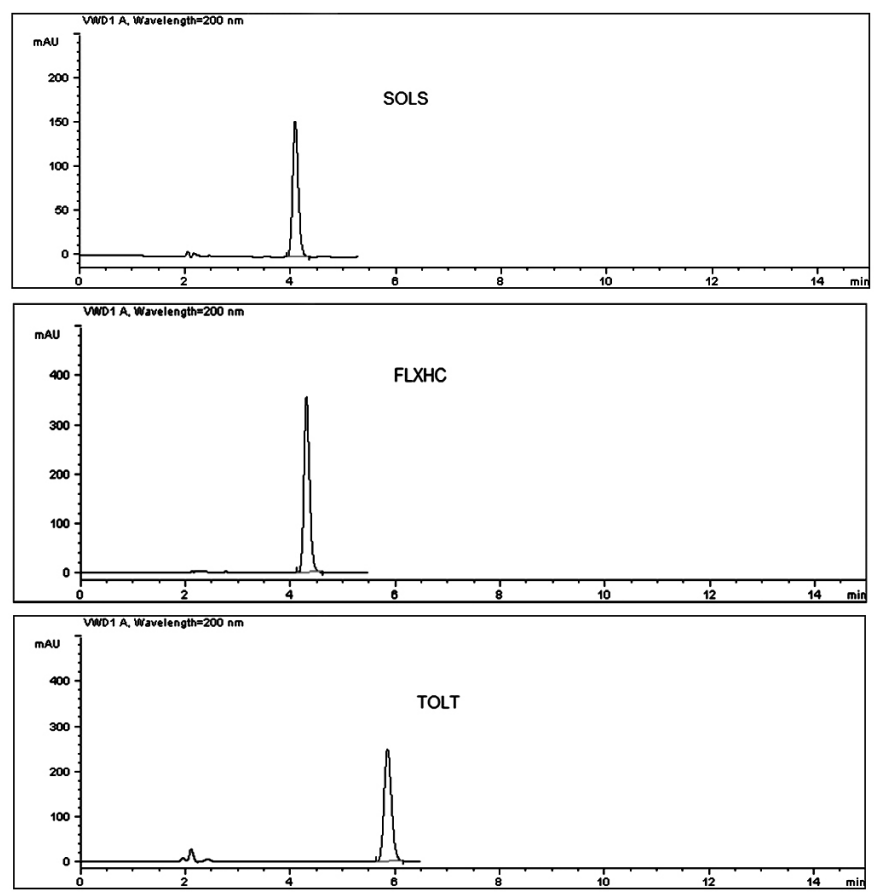

Fig. 2: The chromatograms of SOLS $(10 \mu \mathrm{g} / \mathrm{mL})$, FLXHC and TOLT (20 $\mu \mathrm{g} / \mathrm{mL})$.
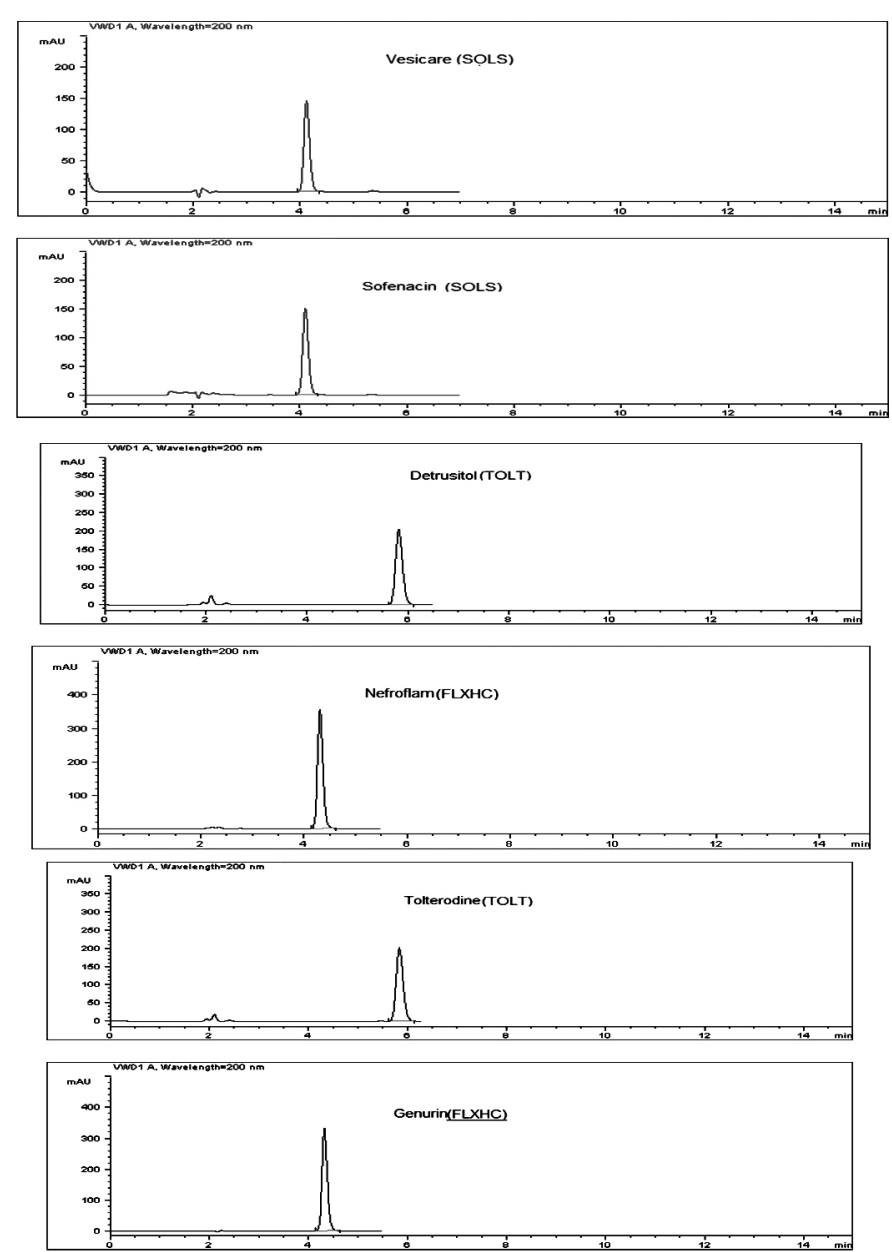

Fig. 3: The chromatograms of SOLS $(10 \mu \mathrm{g} / \mathrm{mL})$, FLXHC and TOLT (20 $\mu \mathrm{g} / \mathrm{mL}$ ) in dosage forms.

\section{Method validation}

The HPLC method was validated in terms of accuracy, precision, limit of detection (LOD), limit of quantification (LOQ), linearity, range and robustness according to the ICH guidelines [43]. LOD and LOQ were calculated from the standard deviation of responses and slopes using signal-to-noise ratio.

System suitability was verified by injecting ten replicates of solutions containing 10, 20 and $20 \mu \mathrm{g} / \mathrm{mL}$ for SOLS, FLXHC and TOLT drugs, respectively. Various parameters for acceptability of the method were indicated by relative standard deviation ( $\% \mathrm{RSD}$ ) of peak areas that did not exceed $2 \%$, the theoretical plates numbers (N) was at least 2000 per each peak and tailing factors was not more than 1.5 for SOLS, FLXHC and TOLT. The results are listed in Table 1.

Table 1. System suitability parameters of SOLS, FLXHC and TOLT drugs for the proposed method.

\begin{tabular}{|c|c|c|c|}
\hline Parameter & SOLS & FLXHC & TOLT \\
\hline Theoretical plates & 8297 & 8910 & 9576 \\
\hline \%RSD (Peak area) & 0.184 & 0.407 & 0.430 \\
\hline Tailing factor & 1.230 & 1.180 & 1.160 \\
\hline
\end{tabular}

Linearity

The calibration curves were obtained by plotting the peak area against concentration for linearity of SOLS, FLXHC and TOLT drugs within the concentration range of $0.1-100 \mu \mathrm{g} / \mathrm{mL}$. The results obtained for the calibration plots of SOLS, FLXHC and TOLT drugs are provided in Table 2. 
Table 2. Linearity parameters of the proposed method.

\begin{tabular}{|c|c|c|c|}
\hline Parameter & SOLS & FLXHC & TOLT \\
\hline Slope & 94.957 & 119.65 & 110.80 \\
\hline Intercept & 55.754 & 14.316 & 74.231 \\
\hline Correlation coefficient $\left(\mathrm{R}^{2}\right)$ & 0.9993 & 0.9999 & 0.9991 \\
\hline LOD $(\mu \mathrm{g} / \mathrm{mL})$ & 0.0180 & 0.0170 & 0.0160 \\
\hline LOQ $(\mu \mathrm{g} / \mathrm{mL})$ & 0.0540 & 0.0520 & 0.0490 \\
\hline
\end{tabular}

Table 3. Precision data for the proposed method.

\begin{tabular}{|c|c|c|c|c|c|}
\hline \multirow{2}{*}{ Drug } & \multirow{2}{*}{$\begin{array}{l}\text { Concentration } \\
(\mu \mathrm{g} / \mathrm{mL})\end{array}$} & \multicolumn{2}{|c|}{ Intra-day precision } & \multirow{2}{*}{$\begin{array}{c}\% \text { Mean } \\
\text { Recovery } \pm \text { SD }\end{array}$} & \multirow{2}{*}{ Mean \%RSD } \\
\hline & & Amount found ${ }^{(a)}$ & \%Recovery ${ }^{(a)}$ & & \\
\hline \multirow{3}{*}{ SOLS } & 1.00 & 0.998 & 99.80 & \multirow{3}{*}{$99.800 \pm 0.550$} & \multirow{3}{*}{0.551} \\
\hline & 10.0 & 9.930 & 99.30 & & \\
\hline & 50.0 & 50.21 & 100.4 & & \\
\hline \multirow{3}{*}{ FLXHC } & 5.00 & 5.020 & 100.4 & \multirow{3}{*}{$100.43 \pm 0.570$} & \multirow{3}{*}{0.567} \\
\hline & 40.0 & 40.16 & 100.4 & & \\
\hline & 70.0 & 70.33 & 100.5 & & \\
\hline \multirow{3}{*}{ TOLT } & 7.00 & 7.100 & 101.4 & \multirow{3}{*}{$100.00 \pm 1.270$} & \multirow{3}{*}{1.270} \\
\hline & 30.0 & 29.92 & 99.70 & & \\
\hline & 80.0 & 79.19 & 98.90 & & \\
\hline \multirow{2}{*}{ Drug } & \multirow{2}{*}{$\begin{array}{l}\text { Concentration } \\
(\mu \mathrm{g} / \mathrm{mL})\end{array}$} & \multicolumn{2}{|c|}{ Inter-day precision } & \multirow{2}{*}{$\begin{array}{c}\text { Mean } \\
\% \text { Recovery } \pm \text { SD }\end{array}$} & \multirow{2}{*}{$\begin{array}{l}\text { Mean } \\
\text { \%RSD }\end{array}$} \\
\hline & & Amount Found $^{(a)}$ & \%Recovery ${ }^{(a)}$ & & \\
\hline \multirow{3}{*}{ SOLS } & 1.00 & 0.996 & 99.60 & \multirow{3}{*}{$99.70 \pm 0.22$} & \multirow{3}{*}{0.22} \\
\hline & 10.0 & 9.970 & 99.70 & & \\
\hline & 50.0 & 50.01 & 100.0 & & \\
\hline \multirow{3}{*}{ FLXHC } & 5.00 & 4.970 & 99.40 & \multirow{3}{*}{$100.3 \pm 0.79$} & \multirow{3}{*}{0.78} \\
\hline & 40.0 & 40.34 & 100.9 & & \\
\hline & 70.0 & 70.43 & 100.6 & & \\
\hline \multirow{3}{*}{ TOLT } & 7.00 & 7.080 & 101.1 & \multirow{3}{*}{$100.4 \pm 0.61$} & \multirow{3}{*}{0.60} \\
\hline & 30.0 & 29.97 & 99.90 & & \\
\hline & 80.0 & 80.22 & 100.3 & & \\
\hline
\end{tabular}

${ }^{\mathrm{a}}$ Mean of three different samples for each concentration.

\section{Precision}

The repeatability of the proposed method was evaluated by assaying three samples solutions of SOLS, FLXHC and TOLT within the same day and under the same experimental conditions (intra-day). The precision was evaluated by assaying solutions on three consecutive days (Inter-day). Peak areas were determined and the precision was expressed as relative standard deviation $(\%$ RSD $)<2$. From the data obtained in Table 3, the developed RP-HPLC method was found to be precise.

Accuracy

The accuracy of the method was determined by calculating recoveries of SOLS, FLXHC and TOLT drugs by standard addition method. Known amounts of SOLS, FLXHC and TOLT were added to pre-quantified sample solutions, and the total amounts of these drugs were determined by measuring the peak areas and draw relation between concentration and area once when standard alone and the other when adding sample. The results are listed in Table 4.

\section{Robustness}

To determine the robustness of the developed method, experimental conditions were purposely altered. The flow rate and $\mathrm{pH}$ values were changed by \pm 0.2 units and the mobile phase (buffer: acetonitrile $\mathrm{v} / \mathrm{v}$ ) wAS changed by \pm 1 . The results are provided in Table 5. Form these results; it was observed that there were no significant changes in the obtained chromatograms which demonstrate that the HPLC method developed was robust. forms

Determination of SOLS, FLXHC and TOLT drugs in their dosage

The assay was performed on the marketed formulations of SOLS (Vesicare and Sofenacin tablet), FLXHC (Genurin and Nephroflam tablets) and TOLT (Detrusitol capsule and Tolterodine tablet) by taking the equivalent weight of one tablet, dissolving it in the mobile phase, diluting it and injecting in HPLC.
The results are listed in Table 6. Student t- and F- tests (at 95\% confidence level) were applied through the comparison between the proposed method and reported chromatographic methods $[8,21,25]$. The results showed that the calculated $\mathrm{t}$ - and F- values did not exceed the theoretical values, thus the proposed method is valid (Table 7).

\section{CONCLUSION}

The proposed RP-HPLC method is simple, precise, accurate sensitive, selective and validated for quantitative determination of SOLS, FLXHC and TOLT drugs in bulk and in their pharmaceutical dosage forms with satisfactory results. The results are in good agreement with the reported methods. The calibration graphs for these drugs were found to be linear in the range of 0.1$100 \mu \mathrm{g} / \mathrm{mL}$ for SOLS, FLXHC and TOLT drugs, with a correlation coefficient of $0.9993,0.9999$ and 0.9991 for SOLS, FLXHC and TOLT drugs respectively. Therefore, the proposed method showed more selectivity and sensitivity than the other reported chromatographic methods for SOLS, the linearity ranges of $20-200 \mu \mathrm{g} / \mathrm{mL}$ [7], 30-70 $\mu \mathrm{g} / \mathrm{mL}$ [8], 1-30 $\mu \mathrm{g} / \mathrm{mL}$ [10] and 15-75 $\mu \mathrm{g} / \mathrm{mL}$ [11], for FLXHC, the linearity ranges of $1-250 \mu \mathrm{g} / \mathrm{mL}[20]$ and $2-40 \mu \mathrm{g} / \mathrm{mL}$ [21] and for TOLT, the linearity ranges of $10-60 \mu \mathrm{g} / \mathrm{mL}$ [23] and $10-30 \mu \mathrm{g} / \mathrm{mL}$ [24]. Also this study can be used as a versatile analytical tool suitable for the assay of these drugs and quality control experiments in pharmaceutical companies and therapeutic drug monitoring laboratories. 
Table 4. Standard addition data of SOLS, FLXHC and TOLT drugs using proposed method.

\begin{tabular}{|c|c|c|c|c|}
\hline Drug & Taken $(\mu \mathrm{g} / \mathrm{mL})$ & Amount of standard added $(\mu \mathrm{g} / \mathrm{mL})$ & Found $(\mu \mathrm{g} / \mathrm{mL})$ & \%Recovery \\
\hline \multirow{6}{*}{ SOLS } & \multirow{6}{*}{10} & 2.50 & 12.44 & 99.52 \\
\hline & & 5.00 & 14.90 & 99.33 \\
\hline & & 7.50 & 17.35 & 99.14 \\
\hline & & 10.0 & 19.97 & 99.85 \\
\hline & & 15.0 & 24.84 & 99.36 \\
\hline & & 20.0 & 29.77 & 99.23 \\
\hline \multirow{6}{*}{ FLXHC } & \multirow{6}{*}{20} & 5.00 & 24.98 & 99.92 \\
\hline & & 10.0 & 29.72 & 99.10 \\
\hline & & 15.0 & 35.28 & 100.8 \\
\hline & & 20.0 & 39.86 & 99.65 \\
\hline & & 30.0 & 49.55 & 99.10 \\
\hline & & 40.0 & 59.40 & 99.00 \\
\hline \multirow{6}{*}{ TOLT } & \multirow{6}{*}{20} & 5.00 & 24.88 & 99.52 \\
\hline & & 10.0 & 29.75 & 99.17 \\
\hline & & 15.0 & 35.37 & 101.0 \\
\hline & & 20.0 & 40.31 & 100.7 \\
\hline & & 30.0 & 49.90 & 99.80 \\
\hline & & 40.0 & 59.67 & 99.45 \\
\hline
\end{tabular}

Table 5. System suitability parameters and robustness results of $10 \mu \mathrm{g} / \mathrm{mL}$ (SOLS), $20 \mu \mathrm{g} / \mathrm{mL}$ (FLXHC) and $20 \mu \mathrm{g} / \mathrm{mL}$ (TOLT).

\begin{tabular}{|c|c|c|c|c|c|}
\hline System suitability Parameters & No & & SOLS & FLXHC & TOLT \\
\hline \multirow{12}{*}{ Tailing factor } & 1. & \multicolumn{2}{|c|}{ Flow rate $(\mathrm{mL} / \mathrm{min})$} & & \\
\hline & & 0.8 & 1.23 & 1.176 & 1.165 \\
\hline & & 1.0 & 1.23 & 1.180 & 1.160 \\
\hline & & 1.2 & 1.20 & 1.177 & 1.133 \\
\hline & 2. & $\mathrm{pH}$ of Buffer & & & \\
\hline & & $2.8 / 5.3$ & 1.21 & 1.187 & 1.169 \\
\hline & & $3.0 / 5.5$ & 1.23 & 1.180 & 1.160 \\
\hline & & $3.2 / 5.7$ & 1.19 & 1.153 & 1.159 \\
\hline & 3. & Buffer: ACE & & & \\
\hline & & $49: 51$ & 1.23 & 1.169 & 1.182 \\
\hline & & $50: 50$ & 1.23 & 1.180 & 1.160 \\
\hline & & $51: 49$ & 1.23 & 1.192 & 1.181 \\
\hline \multirow{12}{*}{ Theoretical plates } & 1. & \multicolumn{2}{|c|}{ Flow rate $(\mathrm{mL} / \mathrm{min})$} & & \\
\hline & & 0.8 & 10053 & 10579 & 11582 \\
\hline & & 1.0 & 8297 & 8910 & 9576 \\
\hline & & 1.2 & 7293 & 8401 & 8427 \\
\hline & 2. & $\mathrm{pH}$ of Buffer & & & \\
\hline & & $2.8 / 5.3$ & 8503 & 9193 & 9991 \\
\hline & & $3.0 / 5.5$ & 8297 & 8910 & 9576 \\
\hline & & $3.2 / 5.7$ & 8644 & 7818 & 9545 \\
\hline & 3. & Buffer: ACE & & & \\
\hline & & $49: 51$ & 8187 & 9117 & 9610 \\
\hline & & $50: 50$ & 8297 & 8910 & 9576 \\
\hline & & $51: 49$ & 8761 & 8938 & 9840 \\
\hline \multirow{12}{*}{$\%$ Recovery } & 1. & \multicolumn{2}{|c|}{ Flow rate $(\mathrm{mL} / \mathrm{min})$} & & \\
\hline & & 0.8 & 98.90 & 99.90 & 100.06 \\
\hline & & 1.0 & 99.10 & 100.2 & 100.03 \\
\hline & & 1.2 & 101.1 & 100.4 & 99.080 \\
\hline & 2. & $\mathrm{pH}$ of Buffer & & & \\
\hline & & $2.8 / 5.3$ & 100.6 & 99.70 & 99.68 \\
\hline & & $3.0 / 5.5$ & 99.10 & 100.2 & 100.03 \\
\hline & & $3.2 / 5.7$ & 100.7 & 100.1 & 100.20 \\
\hline & 3. & Buffer: ACE & & & \\
\hline & & $49: 51$ & 98.80 & 99.70 & 100.70 \\
\hline & & $50: 50$ & 99.10 & 100.2 & 100.03 \\
\hline & & $51: 49$ & 100.3 & 99.80 & 100.50 \\
\hline
\end{tabular}

SD: Standard deviation of six different determinations, ACE: Acetonitrile. 
Table 6. Analysis of marketed dosage forms by the proposed method.

\begin{tabular}{|c|c|c|c|c|}
\hline \multirow{2}{*}{ Dosage form } & \multirow{2}{*}{ Drug } & Label claim $(\mathrm{mg})$ & Found $(\mathrm{mg})$ & \%Recovery \\
\hline Vesicare tablet & \multirow{2}{*}{ SOLS } & 5.00 & 4.950 & $99.10 \pm 0.72$ \\
\cline { 4 - 5 } Sofenacin tablet & & 10.0 & 10.12 & $101.2 \pm 0.91$ \\
\hline Genurin tablet & \multirow{2}{*}{ FLXHC } & 200 & 200.4 & $100.2 \pm 0.25$ \\
\cline { 4 - 5 } Nephroflam tablet & & 200 & 199.4 & $99.70 \pm 0.39$ \\
\hline Detrusitol capsules & \multirow{2}{*}{ TOLT } & 4.00 & 4.000 & $100.0 \pm 0.35$ \\
\hline Tolterodine tablet & & 2.00 & 2.010 & $100.7 \pm 0.38$ \\
\hline
\end{tabular}

${ }^{\mathrm{a}}$ Mean of six different determinations

Table 7. Statistical analysis of data obtained for the determination of SOLS, FLXHC and TOLT drugs.

\begin{tabular}{|c|c|c|c|c|c|c|}
\hline Parameters & $\begin{array}{l}\text { Proposed } \\
\text { method }\end{array}$ & $\begin{array}{l}\text { Reported } \\
\text { method [8] }\end{array}$ & $\begin{array}{l}\text { Proposed } \\
\text { method }\end{array}$ & $\begin{array}{l}\text { Reported } \\
\text { method [21] }\end{array}$ & $\begin{array}{l}\text { Proposed } \\
\text { method }\end{array}$ & $\begin{array}{l}\text { Reported method } \\
{[25]}\end{array}$ \\
\hline & \multicolumn{2}{|c|}{ SOLS } & \multicolumn{2}{|c|}{ FLXHC } & \multicolumn{2}{|c|}{ TOLT } \\
\hline $\mathrm{SD}$ & 0.009 & 0.017 & 0.012 & 0.012 & 0.007 & 0.013 \\
\hline Std. Error & 0.003 & 0.007 & 0.005 & 0.005 & 0.003 & 0.005 \\
\hline F-value & 4.270 & ------------- & 1.010 & ----------- & 4.190 & -------- \\
\hline t-value & 1.820 & ------------ & 0.493 & ----------- & 0.300 & --------- \\
\hline
\end{tabular}

Tabulated $\mathrm{F}$ and $\mathrm{t}$ values at $95 \%$ confidence limit: 6.39 and 2.77 , respectively.

\section{ACKNOWLEDGMENT}

The authors would like to express their gratitude to the National Organization for Drug Control and Research (NODCAR, Egypt) for providing instruments and the means necessary to accomplish this work.

\section{REFERENCES}

1. M. Maniscalco, D. S. Franco, W. R. Wolowich, R. T. Colon, Clin. Ther. $28,1247,(2006)$.

2. K. J. Kreder, Urol. Clin. North Am. 33, 483, (2006).

3. S. C. Sweetman, Martindale, The Complete Drug Reference, 36th ed. Pharmaceutical Press, London, 2009.

4. B. K. Malhotra, P. Glue, K. Sweeney, R. Anziano, J. Mancuso, P. Wicker, Clin. Pharmacol. Therap. 81, 377, (2007).

5. M. J. O. Neil, The Merck index, An Encyclopedia of Chemicals, Drugs and Biological. 14th ed. New Jersey: Merck Research Laboratories, Whitehouse station, 2006.

6. B. V. R. Reddy, B. S. Reddy, N. V. V. S. S. Raman, R. K. Subhash, C. Rambabu, J. Chem. 2013, 1, (2013).

7. M. M. Annapurna, G. Sowjanya, M. S. Naidu, D. Lohithasu, Chem. Sci. Trans. 3, 602, (2014).

8. V. Vijayasree, D. A. Kumar, J. V. L. N. S. Rao, Pharmanest 4, 206, (2013).

9. S. R. Krishna, B. M. Rao, N. S. Rao, J. Chromatogr. Sci. 48, 807, (2010).

10. N. Desai, S. H. Syed, S. G. Vasanthraju, A. Karthik, N. Udupa, Int. J. Pharm. Pharm. Sci. 3, 70 (2011).

11. D. S. Israel, K. Krishnachaitanya, D. Gowrisankar, IJPSR, 4, 4343, (2013).

12. N. Paliwal, P. Jain, N. Dubey, S. Sharma, S. Khurana, R. Mishra, S.K. Paliwal, Int. J. Drug Dev. Res. 5, 91, (2013).

13. P. S. Babu, SK. R. Parveen, K. B. Chandrasekar, B. R. Challa, B. Z. Sh. Awen, JSRR, 3, 1905, (2014).

14. S. B. Puttagunta, R. P. Shaik, C. K. Bannoth, B. S. R. Challa, B. Z. Sh. Awen, J. Anal. Sci. Tech. 5, 1, (2014).

15. T. Oki, S. Sato, K. Miyata, S. Yamada, British J. Pharmacol. 145, 219, (2005).

16. D. Desai, G. Mehta, D. Ruikar, R. A Jain, S. J. Rajput, Asian J. Pharm. Biol. Res. 1, 310, (2011).

17. S. B. Wankhede, K. Somani, S. S. Chitlange, Int. J. Chem. Tech. Res. 3 , 2003, (2011)

18. M. V. Attimarad, N. S. Harsha, R. S. Setty, J. Liq. Chromatogr. Rel. Tech. $35,768,(2012)$
19. A. El-Gindy, R. A. Abdel-Salam, S. Sallam, Drug Dev. Ind. Pharm. 34, $1311,(2008)$.

20. A. Mahesh, J. Young Pharm. 2, 280, (2010).

21. R. N. El-Shaheny, N. M. El-Enany, F. F. Belal, Anal. Methods 6, 1001, (2014).

22. S. A. Kumar, M. Debnath, J. V. L. N. S. Rao, Int. J. Pharm. Pharm. Sci. $5,665,(2013)$.

23. S. K. R. Parveen, P. S. Babu, K. B. Chandrasekar, B. R. Challa, Der Pharmacia Lett. 6, 246, (2014).

24. N. Ramathilagam, M. Meeradevi, P. Solairaj, S. C. Rajesh, Int. J. Pharm. Bio. Sci. 2, 332, (2012).

25. S. K. Shetty, A. Shah, Int. J. Pharm. Tech. Res. 3, 1083, (2011).

26. S. R. Krishna, B. M. Rao, N. S. Rao, Rasayan J. Chem. 2, 144, (2009).

27. S. M. Mhamunkar, R. Y. Vyavaharkar, S. Bhoir, Int. J. Pharm. Pharm. Sci. 4, 319, (2012).

28. M. V. B. Rao, B. C. Reddy, T. S. Rao, J. R. Mohanty, Res. J. Pharm. Bio. Chem. Sci. 1, 136, (2010).

29. R. Yanamandra, C. S. Vadla, U. Puppala, B. Patro, Y. L. N. Murthy, P. A. Ramaiah, Sci. Pharm. 80, 101, (2012).

30. G. D. Teja, Ch. D. Dasu, P. S. Babu, P. Ravisankar, JCPS, 6, 195, (2013).

31. R. Seetharaman, K. S. Lakshmi, Int. J. Res. Pharm. Biomed. Sci. 2, 1052, (2011).

32. M. Attimarad, J. Basic Clin. Pharm. 2, 53, (2011).

33. M. Attimarad, J. Iranian Chem. Soc. 9, 551, (2012).

34. S. K. Shetty, A. Shah, IJPSR, 2, 1456, (2011).

35. S. Vanilatha, M. M. Theresa, N. Prasanna, D. S. Kumari, B. Harika, P. Sirisha, M. A. Xavier, K. G. B. Kumari, IJSID, 1, 288, (2011).

36. S. M. Fraihat, H. S. Khatib, Asian J. Chem. 25, 1887, (2013).

37. M. S. Rizk, F. M. Abdel-Haleem, Electrochim. Acta 55, 5592, (2010).

38. M. M. Sakr, R. M. El Nashar, Talanta 96, 153, (2012).

39. M. W. Nassar, K. A. Attia, H. M. Abou-Seada, A. E. Allam, IJPSR, 4, 3845, (2013).

40. M. M. Ghoneim, M. A. El-Attar, S. A. Razeq, Central Eur. J. Chem. 5, 496, (2007).

41. D. Kul, J. Anal. Chem. 69, 970, (2014).

42. P. Macikova, J. Skopalova, P. Cankar, B. Papouskova, R. Strakova, D. Jirovsky, V. Maier, Electroanalysis 25, 205, (2013).

43. ICH, Stability Testing of New Drug Substances and Products. International Conference on Harmonization, IFPMA, Geneva, 1993. 